\title{
A Simple Reaction for DNA Sensing and Chemical Delivery
}

\author{
Elia Janett, Kim-Long Diep, Katharina M. Fromm, and Christian G. Bochet*
}

\begin{abstract}
Reactions templated by nucleic acids are currently at the heart of applications in biosensing and drug release. The number of chemical reactions selectively occurring only in the presence of the template, in aqueous solutions, and at room temperature and able to release a chemical moiety is still very limited. Here, we report the use of the $p$-nitrophenyl carbonate (NPC) as a new reactive moiety for DNA templated reactions releasing a colored reporter by reaction with a simple amine. The easily synthesized $p$-nitrophenyl carbonate was integrated in an oligonucleotide and showed a very good stability as well as a high reactivity toward amines, without the need for any supplementary reagent, quantitatively releasing the red $p$-nitrophenolate with a half-life of about $1 \mathrm{~h}$.
\end{abstract}

KEYWORDS: nucleic acids, sensing, click chemistry, templation, carbonate, release
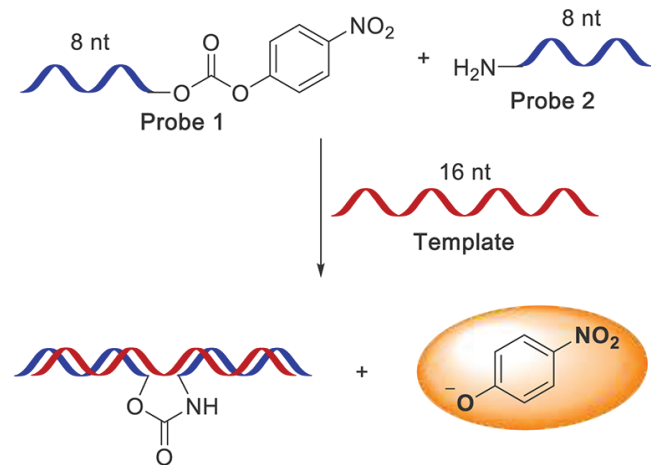

$S_{p}^{\mathrm{c}}$ ensing and release events are crucial operations in Nature, in particular in complex organisms. Evolution led to the emergence of highly specific sensing by exploiting the pairing of complementary nucleotides. Coupling this molecular recognition event to a chemical reaction is the key to a highly precise and selective release of chemicals. While traditional bimolecular reactions suffer from low reaction rates if the concentration of the reagents is below $1-10 \mu \mathrm{M}$, the use of DNA or RNA strands as templates allows the increase of the effective concentration of the reaction partners, bringing them in proximity with each other and hence accelerating the reaction rate. ${ }^{1}$ This was first explored by Orgel $^{2}$ and Gilham, ${ }^{3}$ while Joyce ${ }^{4}$ used DNA strands for the directed ligation of a peptide with an oligonucleotide.

Nowadays, many other reactions can occur selectively in the presence of a nucleic acid template. Their characteristics and scopes are well presented in several reviews. ${ }^{1,5-9}$ The native chemical ligation proposed by Seitz ${ }^{10}$ and Winssinger ${ }^{11}$ or the formation of amide bonds proposed by Abe and Ito, ${ }^{12} \mathrm{Li}^{13}$ and Seeman and Canary ${ }^{14}$ are representative examples. Abe and Ito as well as Kool showed the efficiency of the nucleophilic attack of phosphorothioates or thiols on tosylates ${ }^{15}$ or halides, ${ }^{16-18}$ as well as on electrophilic phosphorothioesters. ${ }^{19}$ A templated aromatic nucleophilic substitution was also developed by Abe and Ito. ${ }^{20}$ One of the currently most used reactions is the Staudinger reaction of azides with phosphines ${ }^{21-24}$ or ruthenium complexes. ${ }^{25}$ Photochemistry has also been exploited by several research groups. ${ }^{26-29}$ The tetrazine-based reaction ${ }^{30}$ as well as several reactions that form $\mathrm{C}-\mathrm{C}$ bonds, like the Wittig reaction, ${ }^{31,32}$ the aldol-type condensation, ${ }^{3,34}$ the Diels-Alder ligation, ${ }^{35}$ and the Heck cross-coupling ${ }^{31}$ are further examples, together with the formation of boronates. ${ }^{36}$
While the above examples mainly focus on linking moieties together via a template, the number of reactions that lead to the release of a useful chemical entity is however much lower. First examples are the release of a nitrophenolate molecule from the templated reaction of a nitrophenyl ester with an imidazole ${ }^{37}$ and the release of a coumarin moiety from a coumarinyl ester. ${ }^{38}$

In times of increasing bacterial resistance, we got interested in this type of chemistry in order to detect bacteria (and other microbes) based on their genetic information released, e.g., by extracellular RNA. ${ }^{40}$ This detection should be highly sensitive, fast, and able to release, e.g., a signaling moiety or an active compound. Most of the above reactions have not been exploited for the delivery of an active compound, showing stability or reactivity issues, and cannot be applied to oligonucleotide sensing in physiological conditions. Such a system hence must work in water, at room temperature, at almost neutral $\mathrm{pH}$, and should not require additional reagents or catalysts, which are potentially cytotoxic. ${ }^{6}$

Here, we present the synthesis, the assembly, and the kinetic analysis of two systems based on a DNA probe derived from Listeria monocytogenes and containing a $p$-nitrophenyl carbonate (NPC) able to release a colored $p$-nitrophenolate upon attack of a DNA probe modified with a terminal hexylamine in a 3-strand strategy (Charts 1 and 2). The NPC represents a new function 
Chart 1. DNA-Templated Reaction of the $p$-Nitrophenyl Carbonate
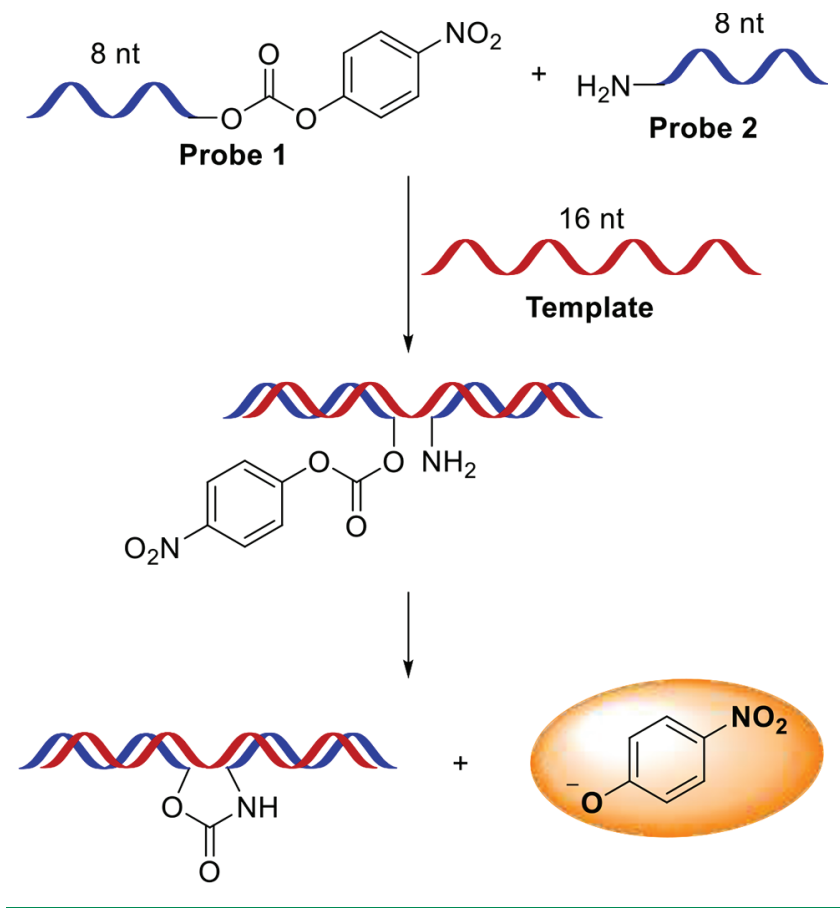

Chart 2. Proof of Principle Using a 2-Strand Model
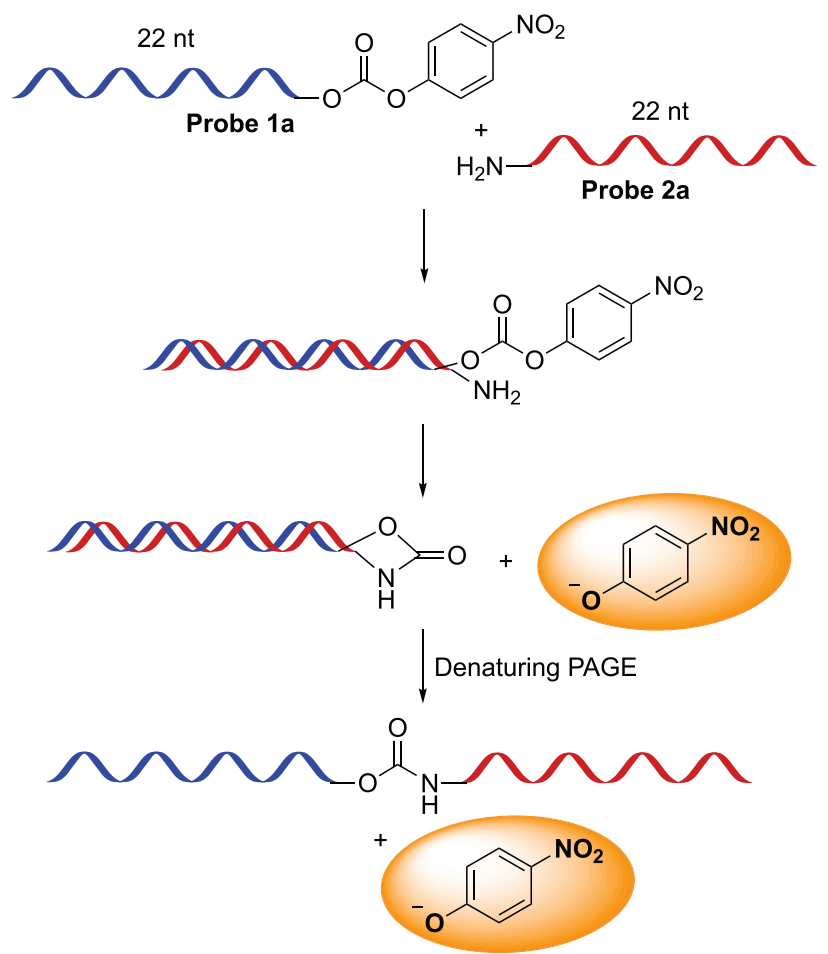

for DNA-templated nucleophilic substitutions. It was easily synthesized and introduced on oligonucleotides, showing good stability and reactivity in physiological conditions. The system works in PBS buffer at $\mathrm{pH} 7.4$ or higher and at room temperature, in the presence of picomoles of template, without any additional reagent, solvent, or base. It therefore broadens the currently limited panel of DNA-templated reactions suitable for the delivery of active molecules, simply replacing the $p$ nitrophenol with an active compound.

\section{NPC SYNTHESIS}

The NPC function was identified after initial stability issues when working with the $p$-nitrophenyl ester described by Taylor. ${ }^{37}$ Following a report by Hamachi, ${ }^{39}$ who proposed an acyl imidazole function for protein ligation, we envisioned the $p$ nitrophenyl carbonate as a species that shows the advantage of being more stable than the $p$-nitrophenyl ester and more reactive than the acyl imidazole (see SI). An NPC containing an azide terminus, for the connection with the oligonucleotide, was easily synthesized in three steps with good yields using either phosgene or disuccinimidyl carbonate (DSC) (Scheme 1).

Scheme 1. Synthesis of the 2-Azidoethyl 4-Nitrophenyl Carbonate

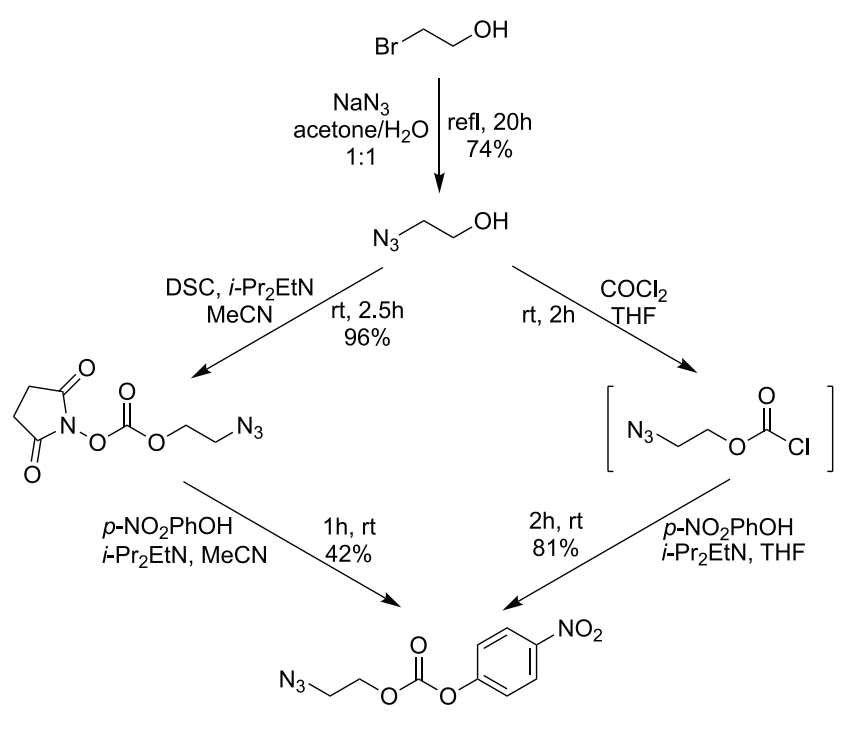

As a first step, in order to follow the DNA-templated reaction by denaturing polyacrylamide gel electrophoresis (PAGE), we decided to work with only two oligodeoxynucleotides (ODN), having complementary sequences and with two reactive functions at the $3^{\prime}$ and $5^{\prime}$ termini (Chart 2). Since the reaction ligates the two strands, the final product can be easily distinguished from the initial reacting strands. The two probes were designed to be fully complementary with a length of 22 nucleotides in order to have a strong hybridization at room temperature. The $p$-nitrophenyl carbonate ODN (Probe 1a) was obtained by $\mathrm{Cu}(\mathrm{I})$ catalyzed azide-alkyne cycloaddition of the commercially available 5 '-hexynyl-ODN with the synthesized 2-azidoethyl 4-nitrophenyl carbonate (Scheme 2). The amino-modified ODN with a hexyl-amine linker at the $3^{\prime}$ position (Probe 2a) is commercially available. In a control

Scheme 2. Synthesis of Probe 1a

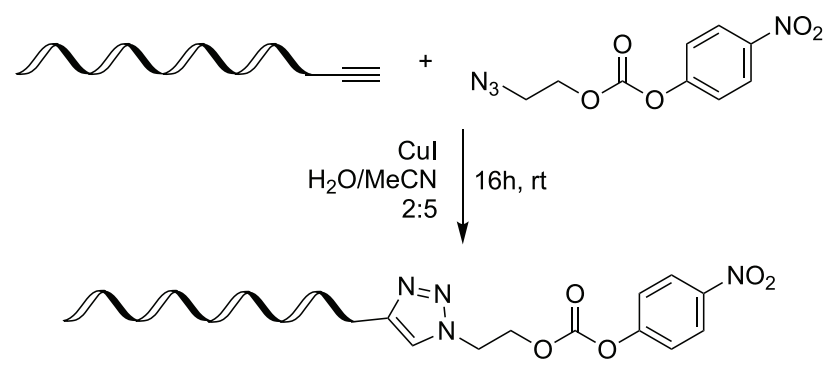


experiment, we used a second, noncomplementary strand

(Control Probe).

\author{
hexynyl-5'-ODN: \\ 5-hexynyl-5'-AAT GAT AAA GTG TGG CGC ATG C-3' \\ Probe 2a: \\ 5'-GCA TGC GCC ACA CTT TAT CAT T-3'- $\left(\mathrm{CH}_{2}\right)_{6} \mathrm{NH}_{2}$ \\ Control Probe: \\ $\mathrm{H}_{2} \mathrm{~N}\left(\mathrm{CH}_{2}\right)_{6}-5^{\prime}-\mathrm{C}$ GTA CGC GGT GTG AAA TAG TAA-3'
}

\section{SYNTHESIS OF PROBE $1 \mathrm{~A}$}

A solution of the 5 -hexynyl-ODN, 50 equiv of the azide and 10 equiv of $\mathrm{CuI}$ in a mixture of $\mathrm{ddH}_{2} \mathrm{O}$ and acetonitrile was left at room temperature overnight, and then purified by precipitation and analyzed by MALDI-TOF spectrometry (see SI for detailed procedure and analyses).

\section{REACTION WITH PROBE 2A}

Mixtures of Probe 1a and Probe 2a in PBS buffer at $\mathrm{pH} 7.4$ were allowed to react at room temperature for the given time, and then analyzed by denaturing PAGE (Figure 1). An immediate

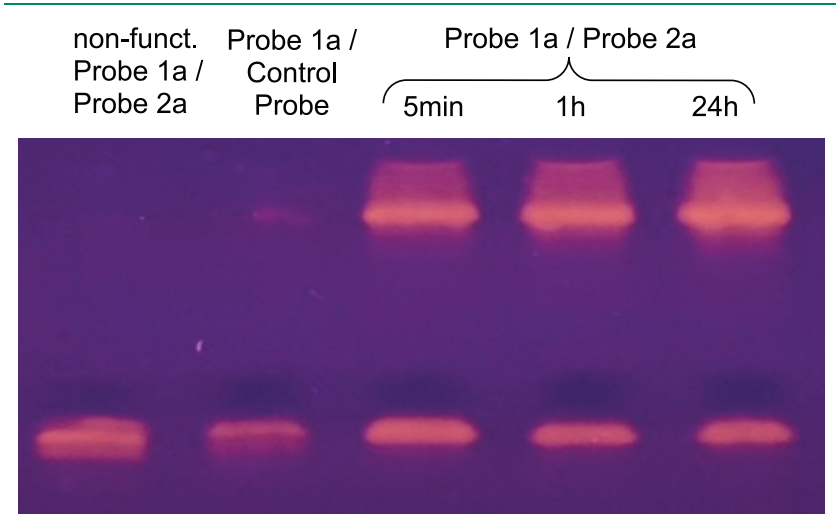

Figure 1. PAGE analysis $(10 \mu \mathrm{M}$ mixtures of Probe 1 and Probe $\mathbf{2}$ in PBS buffer $(150 \mathrm{mM} \mathrm{NaCl}, 4 \mathrm{mM}$ phosphate, $10 \mathrm{mM} \mathrm{MgCl}$ ) at $\mathrm{pH} 7.4$ were let react at room temperature for a given time).

hybridization between the two strands was confirmed by the decrease of $\sim 30 \%$ of the absorbance at $260 \mathrm{~nm}$. Additional bands, observed after only $5 \mathrm{~min}$ of reaction time and corresponding to ODNs of larger size than Probes 1 and 2, indicate that the ligation reaction occurred. As a control, mixtures of Probe 1a and the noncomplementary Control Probe (lane 2) and mixtures of nonfunctionalized Probe 1a and Probe 2a (lane 1) were also allowed to react together for $24 \mathrm{~h}$, showing no ligation.

The ligation between the two strands was further proven by measuring the MALDI-TOF spectrum of the ligated product. The corresponding lane was cut from the gel, the DNA was extracted by letting the gel piece in an elution buffer overnight, and the salts were removed prior to the analysis using $3 \mathrm{k}$ Amicon spin filters. The expected mass was observed.

In order to quantify the release rate of the templated vs the nontemplated reaction, the formation of the $p$-nitrophenolate was followed by UV/vis spectroscopy at $405 \mathrm{~nm}$. The reaction follows a first-order kinetics, and the half-lives were determined between $\mathrm{pH} 7.4$ and 9 (Table 1 ). The reaction rates were affected by the $\mathrm{pH}$ and 3-4 times faster at high rather than neutral $\mathrm{pH}$, presumably due to the protonation state of the amine. ${ }^{41}$ In the presence of a mismatched sequence (control
Table 1. Half-Lives and First-Order Kinetic Constants

\begin{tabular}{lllclc}
\multicolumn{1}{c}{$\mathrm{pH}$} & 7.4 & 8.0 & 8.5 & 9.0 & 9.0 PTO \\
& \multicolumn{5}{c}{ full match } \\
$\tau_{1 / 2}(\min )$ & 141 & 94 & 70 & 44 & 146 \\
$k\left(\times 10^{-3} \mathrm{~min}^{-1}\right)$ & 4.9 & 7.4 & 9.8 & 16 & 4.8 \\
& & \multicolumn{5}{c}{ mismatch } \\
$\tau_{1 / 2}(\min )$ & 465 & 284 & 240 & 162 & 190 \\
$k\left(\times 10^{-3} \mathrm{~min}^{-1}\right)$ & 1.5 & 2.4 & 2.9 & 4.3 & 3.7 \\
\hline
\end{tabular}

probe), the reaction was by a factor of 3-4 slower under similar $\mathrm{pH}$ conditions.

Instead of an amine, the phosphorothioate function (PTO) proposed by Abe, Ito, and Kool ${ }^{15}$ was also tested, showing however a reduced reactivity.

After proving the efficiency of the reaction with the 2-strand model and its potential for the detection of a DNA or RNA template, we challenged the 3-strand system of Chart 1 . Two new sequences were thus designed, allowing to bring the two reactive functions in proximity with each other in the presence of the template (Chart 1). Four different templating sequences were tested, as well as an RNA template, all derived to match an rRNA of L. monocytogenes. Template 1 is a DNA 16-mer, fully complementary. Template 2 is a 17 -mer, the additional base being introduced to add free space for the reactive functions. Templates 3 and 4 are DNA 16-mer containing respectively one and two mismatches, and Template $\mathbf{5}$ is a fully complementary RNA 16-mer.

\author{
hexynyl-5'-0DN: \\ 5-hexynyl-5'- AAT GTG CC -3' \\ Probe 2b: \\ 5'- GAG ATG AG -3'-( $\left(\mathrm{CH}_{2}\right)_{6} \mathrm{NH}_{2}$ \\ Template 1: \\ 5'- GGC ACA TTC TCA TCT C -3' \\ Template 2: \\ 5'- GGC ACA TTA CTC ATC TC -3' \\ Template 3: \\ 5'- GGC ACA GTC TCA TCT C -3' \\ Template 4: \\ 5'- GGA ACA TTC TCA GTC C -3' \\ Template 5: \\ 5'- GGC ACA UUC UCA UCU C -3'
}

\section{SYNTHESIS OF PROBE 1B}

The new probe was synthesized following the same protocol as for the synthesis of 22-mer-NPC-ODN, giving a fully functionalized product in quantitative yield (see SI).

\section{TEMPLATED REACTIONS}

The same procedure was followed as before. Mixtures of Probe 1b, Probe 2b, and Template 1, 2, 3, 4, or 5 in PBS buffer at different $\mathrm{pH}$ were allowed to react at room temperature for the given time (Chart 1). The absorbance at $405 \mathrm{~nm}$ was monitored by $\mathrm{UV} / \mathrm{vis}$ spectroscopy over time to determine the rate of release of the $p$-nitrophenolate. As a control experiment, we performed the reaction in the absence of a template. Slightly shorter half-lives were observed than in the first experiment (Table 2), the functions reacting thus faster than in the 2-strand system. The $\mathrm{pH}$-dependence and the rate difference between the templated and the control reaction followed the same trend as observed above, although with an improvement of the discrimination. The template length did not affect the reactivity 
Table 2. Half-Lives and First-Order Kinetic Constants

\begin{tabular}{|c|c|c|c|c|c|c|c|c|}
\hline $\mathrm{pH}$ & 7.4 & 8.0 & 8.5 & 9.0 & 7.4 & 7.4 & 7.4 & 7.4 \\
\hline Template & T1 & T1 & T1 & $\mathrm{T} 1$ & $\mathrm{~T} 2$ & T3 & T4 & T5 \\
\hline & \multicolumn{8}{|c|}{ templated } \\
\hline$\tau_{1 / 2}(\min )$ & 89 & 74 & 57 & 34 & 84 & 145 & 293 & 69 \\
\hline$k\left(\times 10^{-3} \min ^{-1}\right)$ & 7.8 & 9.3 & 12 & 21 & 8.3 & 4.8 & 2.4 & 10 \\
\hline & \multicolumn{8}{|c|}{ control } \\
\hline$\tau_{1 / 2}(\min )$ & 370 & 316 & 201 & 154 & 370 & 247 & 304 & 241 \\
\hline
\end{tabular}

(column 5) nor the replacement of the DNA template by RNA (column 8). On the other hand, the introduction of a single mismatch is enough to drastically decrease the reactivity (column 6), whereas two mismatches completely inhibit the reaction (column 7 ). Thus, conditions are met for a reasonably fast (34 min) and selective ( $k_{\text {cat }} / k_{\text {uncat }}$ ca. 5$)$ detection of nucleic acid sequences, at picomolar concentration.

In conclusion, the identification of a new function for the release of a chemical entity by nucleic acid templation broadens the still limited panel of reactions suitable for DNA and RNA sensing and for drug delivery in biologically compatible conditions. The $p$-nitrophenyl carbonate functionalized oligonucleotides show a good stability and are quickly assembled. The aromatic core offers the possibility to be further functionalized by introducing self-immolative linkers to simultaneous release of several chemical compounds. Since the released unit is colored, the 3-strand system is ideally suited for fast colorimetric detection of bacteria, as proven here for $L$. monocytogenes. Moreover, depending on the application, the sensitivity can be further improved by any standard spectrometric technique.

\section{ASSOCIATED CONTENT}

\section{Supporting Information}

The Supporting Information is available free of charge at https://pubs.acs.org/doi/10.1021/acssensors.0c00988.

Experimental details, analytical outputs, and kinetic data (PDF)

\section{AUTHOR INFORMATION}

\section{Corresponding Author}

Christian G. Bochet - Department of Chemistry, University of Fribourg, CH-1700 Fribourg, Switzerland; 이이.org/00000003-4267-0523; Email: christian.bochet@unifr.ch

\section{Authors}

Elia Janett - Department of Chemistry, University of Fribourg, $\mathrm{CH}-1700$ Fribourg, Switzerland

Kim-Long Diep - Department of Chemistry, University of Fribourg, CH-1700 Fribourg, Switzerland

Katharina M. Fromm - Department of Chemistry, University of Fribourg, CH-1700 Fribourg, Switzerland; 이이이.org/00000002-1168-0123

Complete contact information is available at:

https://pubs.acs.org/10.1021/acssensors.0c00988

\section{Funding}

The support of the Swiss National Science Foundation (NRP62) and the CTI (grant 17847.1 PFNM-NM) is gratefully acknowledged.
Notes

The authors declare no competing financial interest.

\section{REFERENCES}

(1) Gorska, K.; Winssinger, N. Reactions Templated by Nucleic Acids: More Ways to Translate Oligonucleotide-Based Instructions into Emerging Function. Angew. Chem., Int. Ed. 2013, 52 (27), 68206843.

(2) Böhler, C.; Nielsen, P. E.; Orgel, L. E. Template switching between PNA and RNA oligonucleotides. Nature 1995, 376, 578.

(3) Naylor, R.; Gilham, P. T. Studies on Some Interactions and Reactions of Oligonucleotides in Aqueous Solution*. Biochemistry 1966, 5 (8), 2722-2728.

(4) Bruick, R. K.; Dawson, P. E.; Kent, S. B. H.; Usman, N.; Joyce, G. F. Template-directed ligation of peptides to oligonucleotides. Chem. Biol. 1996, 3 (1), 49-56.

(5) Di Pisa, M.; Seitz, O. Nucleic Acid Templated Reactions for Chemical Biology. ChemMedChem 2017, 12 (12), 872-882.

(6) Percivalle, C.; Bartolo, J.-F.; Ladame, S. Oligonucleotidetemplated chemical reactions: pushing the boundaries of a natureinspired process. Org. Biomol. Chem. 2013, 11 (1), 16-26.

(7) Shibata, A.; Abe, H.; Ito, Y. Oligonucleotide-Templated Reactions for Sensing Nucleic Acids. Molecules 2012, 17 (3), 2446.

(8) Silverman, A. P.; Kool, E. T. Detecting RNA and DNA with Templated Chemical Reactions. Chem. Rev. 2006, 106 (9), 3775-3789.

(9) Li, X.; Liu, D. R. DNA-Templated Organic Synthesis: Nature's Strategy for Controlling Chemical Reactivity Applied to Synthetic Molecules. Angew. Chem., Int. Ed. 2004, 43 (37), 4848-4870.

(10) (a) Grossmann, T. N.; Seitz, O. DNA-Catalyzed Transfer of a Reporter Group. J. Am. Chem. Soc. 2006, 128 (49), 15596-15597. (b) Grossmann, T. N.; Strohbach, A.; Seitz, O. Achieving Turnover in DNA-Templated Reactions. ChemBioChem 2008, 9 (14), 2185-2192. (c) Ficht, S.; Dose, C.; Seitz, O. As Fast and Selective as Enzymatic Ligations: Unpaired Nucleobases Increase the Selectivity of DNAControlled Native Chemical PNA Ligation. ChemBioChem 2005, 6 (11), 2098-2103. (d) Zavoiura, O.; Resch-Genger, U.; Seitz, O. Quantum Dot-PNA Conjugates for Target-Catalyzed RNA Detection. Bioconjugate Chem. 2018, 29, 1690.

(11) Sayers, J.; Payne, R. J.; Winssinger, N. Peptide nucleic acidtemplated selenocystine-selenoester ligation enables rapid miRNA detection. Chem. Sci. 2018, 9 (4), 896-903.

(12) (a) Tse, B. N.; Snyder, T. M.; Shen, Y.; Liu, D. R. Translation of DNA into a Library of 13000 Synthetic Small-Molecule Macrocycles Suitable for in Vitro Selection. J. Am. Chem. Soc. 2008, 130 (46), 15611-15626. (b) He, Y.; Liu, D. R. A Sequential Strand-Displacement Strategy Enables Efficient Six-Step DNA-Templated Synthesis. J. Am. Chem. Soc. 2011, 133 (26), 9972-9975.

(13) Li, Y.; Zhao, P.; Zhang, M.; Zhao, X.; Li, X. Multistep DNATemplated Synthesis Using a Universal Template. J. Am. Chem. Soc. 2013, 135 (47), 17727-17730.

(14) Liu, Y.; Sha, R.; Wang, R.; Ding, L.; Canary, J. W.; Seeman, N. C. $2^{\prime}, 2^{\prime}$-Ligation demonstrates the thermal dependence of DNA-directed positional control. Tetrahedron 2008, 64 (36), 8417-8422.

(15) (a) Silverman, A. P.; Kool, E. T. Quenched autoligation probes allow discrimination of live bacterial species by single nucleotide differences in rRNA. Nucleic Acids Res. 2005, 33 (15), 4978-4986. (b) Sando, S.; Kool, E. T. Imaging of RNA in Bacteria with Self-Ligating 
Quenched Probes. J. Am. Chem. Soc. 2002, 124 (33), 9686-9687. (c) Kleinbaum, D. J.; Kool, E. T. Sandwich probes: two simultaneous reactions for templated nucleic acid detection. Chem. Commun. 2009, 46 (43), 8154-8156. (d) Abe, H.; Kool, E. T. Flow cytometric detection of specific RNAs in native human cells with quenched autoligating FRET probes. Proc. Natl. Acad. Sci. U. S. A. 2006, 103 (2), 263-268.

(16) (a) Harcourt, E. M.; Kool, E. T. Amplified microRNA detection by templated chemistry. Nucleic Acids Res. 2012, 40 (9), e65-e65. (b) Xu, Y.; Karalkar, N. B.; Kool, E. T. Nonenzymatic autoligation in direct three-color detection of RNA and DNA point mutations. Nat. Biotechnol. 2001, 19, 148. (c) Abe, H.; Kondo, Y.; Jinmei, H.; Abe, N.; Furukawa, K.; Uchiyama, A.; Tsuneda, S.; Aikawa, K.; Matsumoto, I.; Ito, Y. Rapid DNA Chemical Ligation for Amplification of RNA and DNA Signal. Bioconjugate Chem. 2008, 19 (1), 327-333. (d) Maruyama, H.; Nakashima, Y.; Shuto, S.; Matsuda, A.; Ito, Y.; Abe, H. An intracellular buildup reaction of active siRNA species from short RNA fragments. Chem. Commun. 2014, 50 (11), 1284-1287.

(17) (a) Onizuka, K.; Nagatsugi, F.; Ito, Y.; Abe, H. Automatic Pseudorotaxane Formation Targeting on Nucleic Acids Using a Pair of Reactive Oligodeoxynucleotides. J. Am. Chem. Soc. 2014, 136 (20), 7201-7204. (b) Onizuka, K.; Chikuni, T.; Amemiya, T.; Miyashita, T.; Onizuka, K.; Abe, H.; Nagatsugi, F. Pseudorotaxane formation via the slippage process with chemically cyclized oligonucleotides. Nucleic Acids Res. 2017, 45 (9), 5036-5047.

(18) Li, X.; Liu, D. R. Stereoselectivity in DNA-Templated Organic Synthesis and Its Origins. J. Am. Chem. Soc. 2003, 125 (34), 1018810189.

(19) (a) Maruyama, H.; Oikawa, R.; Hayakawa, M.; Takamori, S.; Kimura, Y.; Abe, N.; Tsuji, G.; Matsuda, A.; Shuto, S.; Ito, Y.; Abe, H. Chemical ligation of oligonucleotides using an electrophilic phosphorothioester. Nucleic Acids Res. 2017, 45 (12), 7042-7048. (b) Abe, H.; Kimura, Y. Chemical Ligation Reactions of Oligonucleotides for Biological and Medicinal Applications. Chem. Pharm. Bull. 2018, 66 (2), 117-122.

(20) (a) Shibata, A.; Abe, H.; Ito, M.; Kondo, Y.; Shimizu, S.; Aikawa, K.; Ito, Y. DNA templated nucleophilicaromatic substitution reactions for fluorogenic sensing of oligonucleotides. Chem. Commun. 2009, No. 43, 6586-6588. (b) Shibata, A.; Uzawa, T.; Nakashima, Y.; Ito, M.; Nakano, Y.; Shuto, S.; Ito, Y.; Abe, H. Very Rapid DNA-Templated Reaction for Efficient Signal Amplification and Its Steady-State Kinetic Analysis of the Turnover Cycle. J. Am. Chem. Soc. 2013, 135 (38), 14172-14178.

(21) (a) Gorska, K.; Manicardi, A.; Barluenga, S.; Winssinger, N. DNA-templated release of functional molecules with an azidereduction-triggered immolative linker. Chem. Commun. 2011, 47 (15), 4364-4366. (b) Pianowski, Z. L.; Winssinger, N. Fluorescencebased detection of single nucleotide permutation in DNAvia catalytically templated reaction. Chem. Commun. 2007, No. 37, 3820-3822. (c) Pianowski, Z.; Gorska, K.; Oswald, L.; Merten, C. A.; Winssinger, N. Imaging of mRNA in Live Cells Using Nucleic Acid-Templated Reduction of Azidorhodamine Probes. J. Am. Chem. Soc. 2009, 131 (18), 6492-6497.

(22) (a) Franzini, R. M.; Kool, E. T. 7-Azidomethoxy-Coumarins as Profluorophores for Templated Nucleic Acid Detection. ChemBioChem 2008, 9 (18), 2981-2988. (b) Lee, S. H.; Wang, S.; Kool, E. T. Templated chemistry for monitoring damage and repair directly in duplex DNA. Chem. Commun. 2012, 48 (65), 8069-8071. (c) Franzini, R. M.; Kool, E. T. Efficient Nucleic Acid Detection by Templated Reductive Quencher Release. J. Am. Chem. Soc. 2009, 131 (44), 16021-16023. (d) Franzini, R. M.; Kool, E. T. Improved Templated Fluorogenic Probes Enhance the Analysis of Closely Related Pathogenic Bacteria by Microscopy and Flow Cytometry. Bioconjugate Chem. 2011, 22 (9), 1869-1877.

(23) Cai, J.; Li, X.; Yue, X.; Taylor, J. S. Nucleic Acid-Triggered Fluorescent Probe Activation by the Staudinger Reaction. J. Am. Chem. Soc. 2004, 126 (50), 16324-16325.

(24) (a) Abe, H.; Wang, J.; Furukawa, K.; Oki, K.; Uda, M.; Tsuneda, S.; Ito, Y. A Reduction-Triggered Fluorescence Probe for Sensing
Nucleic Acids. Bioconjugate Chem. 2008, 19 (6), 1219-1226. (b) Furukawa, K.; Abe, H.; Hibino, K.; Sako, Y.; Tsuneda, S.; Ito, Y. Reduction-Triggered Fluorescent Amplification Probe for the Detection of Endogenous RNAs in Living Human Cells. Bioconjugate Chem. 2009, 20 (5), 1026-1036. (c) Furukawa, K.; Abe, H.; Wang, J.; Uda, M.; Koshino, H.; Tsuneda, S.; Ito, Y. Reduction-triggered red fluorescent probes for dual-color detection of oligonucleotide sequences. Org. Biomol. Chem. 2009, 7 (4), 671-677. (d) Saneyoshi, H.; Ochikubo, T.; Mashimo, T.; Hatano, K.; Ito, Y.; Abe, H. Triphenylphosphinecarboxamide: An Effective Reagent for the Reduction of Azides and Its Application to Nucleic Acid Detection. Org. Lett. 2014, 16 (1), 30-33. (e) Shibata, A.; Ito, Y.; Abe, H. RNAtemplated molecule release induced protein expression in bacterial cells. Chem. Commun. 2013, 49 (3), 270-272.

(25) (a) Sadhu, K. K.; Winssinger, N. Detection of miRNA in Live Cells by Using Templated RuII-Catalyzed Unmasking of a Fluorophore. Chem. - Eur. J. 2013, 19 (25), 8182-8189. (b) Holtzer, L.; Oleinich, I.; Anzola, M.; Lindberg, E.; Sadhu, K. K.; GonzalezGaitan, M.; Winssinger, N. Nucleic Acid Templated Chemical Reaction in a Live Vertebrate. ACS Cent. Sci. 2016, 2 (6), 394-400. (c) Saarbach, J.; Lindberg, E.; Winssinger, N. Ruthenium-based Photocatalysis in Templated Reactions. Chimia 2018, 72 (4), 207-211.

(26) (a) Chang, D.; Kim, K. T.; Lindberg, E.; Winssinger, N. Accelerating Turnover Frequency in Nucleic Acid Templated Reactions. Bioconjugate Chem. 2018, 29 (1), 158-163. (b) Chang, D.; Lindberg, E.; Winssinger, N. Critical Analysis of Rate Constants and Turnover Frequency in Nucleic Acid-Templated Reactions: Reaching Terminal Velocity. J. Am. Chem. Soc. 2017, 139 (4), 1444-1447. (c) Röthlingshöfer, M.; Gorska, K.; Winssinger, N. Nucleic AcidTemplated Energy Transfer Leading to a Photorelease Reaction and its Application to a System Displaying a Nonlinear Response. J. Am. Chem. Soc. 2011, 133 (45), 18110-18113.

(27) Liu, J.; Taylor, J. S. Template-directed photoligation of oligodeoxyribonucleotides via 4-thiothymidine. Nucleic Acids Res. 1998, 26 (13), 3300-3304.

(28) Tanabe, K.; Nakata, H.; Mukai, S.; Nishimoto, S.-i. Modulated drug release from the stem-and-loop structured oligodeoxynucleotide upon UV-A irradiation in the presence of target DNA. Org. Biomol. Chem. 2005, 3 (21), 3893-3897.

(29) Okamoto, A.; Tanabe, K.; Inasaki, T.; Saito, I. Phototriggered Drug Release from Functionalized Oligonucleotides by a Molecular Beacon Strategy. Angew. Chem., Int. Ed. 2003, 42 (22), 2502-2504.

(30) (a) Wu, H.; Alexander, S. C.; Jin, S.; Devaraj, N. K. A Bioorthogonal Near-Infrared Fluorogenic Probe for mRNA Detection. J. Am. Chem. Soc. 2016, 138 (36), 11429-11432. (b) Wu, H.; Cisneros, B. T.; Cole, C. M.; Devaraj, N. K. Bioorthogonal Tetrazine-Mediated Transfer Reactions Facilitate Reaction Turnover in Nucleic AcidTemplated Detection of MicroRNA. J. Am. Chem. Soc. 2014, 136 (52), 17942-17945. (c) Wu, H.; Yang, J.; Sečkutè, J.; Devaraj, N. K. In Situ Synthesis of Alkenyl Tetrazines for Highly Fluorogenic Bioorthogonal Live-Cell Imaging Probes. Angew. Chem., Int. Ed. 2014, 53 (23), 58055809. (d) Han, H.-S.; Devaraj, N. K.; Lee, J.; Hilderbrand, S. A.; Weissleder, R.; Bawendi, M. G. Development of a Bioorthogonal and Highly Efficient Conjugation Method for Quantum Dots Using Tetrazine-Norbornene Cycloaddition. J. Am. Chem. Soc. 2010, 132 (23), 7838-7839. (e) Devaraj, N. K.; Hilderbrand, S.; Upadhyay, R.; Mazitschek, R.; Weissleder, R. Bioorthogonal Turn-On Probes for Imaging Small Molecules inside Living Cells. Angew. Chem., Int. Ed. 2010, 49 (16), 2869-2872.

(31) Gartner, Z. J.; Kanan, M. W.; Liu, D. R. Expanding the Reaction Scope of DNA-Templated Synthesis. Angew. Chem., Int. Ed. 2002, 41 (10), 1796-1800

(32) Chen, X. H.; Roloff, A.; Seitz, O. Consecutive Signal Amplification for DNA Detection Based on De Novo Fluorophore Synthesis and Host-Guest Chemistry. Angew. Chem., Int. Ed. 2012, 51 (18), 4479-4483.

(33) Huang, Y.; Coull, J. M. Diamine Catalyzed Hemicyanine Dye Formation from Nonfluorescent Precursors through DNA Programmed Chemistry. J. Am. Chem. Soc. 2008, 130 (11), 3238-3239. 
(34) (a) Meguellati, K.; Koripelly, G.; Ladame, S. DNA-Templated Synthesis of Trimethine Cyanine Dyes: A Versatile Fluorogenic Reaction for Sensing G-Quadruplex Formation. Angew. Chem., Int. Ed. 2010, 49 (15), 2738-2742. (b) Koripelly, G.; Meguellati, K.; Ladame, S. Dual Sensing of Hairpin and Quadruplex DNA Structures Using Multicolored Peptide Nucleic Acid Fluorescent Probes. Bioconjugate Chem. 2010, 21 (11), 2103-2109.

(35) El-Sagheer, A. H.; Cheong, V. V.; Brown, T. Rapid chemical ligation of oligonucleotides by the Diels-Alder reaction. Org. Biomol. Chem. 2011, 9 (1), 232-235.

(36) Martin, A. R.; Barvik, I.; Luvino, D.; Smietana, M.; Vasseur, J. J. Dynamic and Programmable DNA-Templated Boronic Ester Formation. Angew. Chem. 2011, 123 (18), 4279-4282.

(37) Ma, Z.; Taylor, J.-S. Nucleic acid-triggered catalytic drug release. Proc. Natl. Acad. Sci. U. S. A. 2000, 97 (21), 11159-11163.

(38) Ma, Z.; Taylor, J.-S. PNA-Based RNA-Triggered Drug-Releasing System. Bioconjugate Chem. 2003, 14 (3), 679-683.

(39) Fujishima, S.-h.; Yasui, R.; Miki, T.; Ojida, A.; Hamachi, I. Ligand-Directed Acyl Imidazole Chemistry for Labeling of MembraneBound Proteins on Live Cells. J. Am. Chem. Soc. 2012, 134 (9), 39613964.

(40) Seviour, T. W.; Winnerdy, F. R.; Lan Li, W.; Xiangyan, S.; Mugunthan, S.; Kohli, G. S.; Shewan, H. M.; Stokes, J.; Rice, S. A.; Phan, A.-T.; Kjelleberg, S. The Biofilm Matrix Scaffold of Pseudomonas Species Consists of Non-Canonically Base Paired Extracellular DNA and RNA. bioRxiv 2019, 527267.

(41) Maruyama, H.; Oikawa, R.; Hayakawa, M.; Takamori, S.; Kimura, Y.; Abe, N.; Tsuji, G.; Matsuda, A.; Shuto, S.; Ito, Y.; Abe, H. Chemical Ligation of Oligonucleotides Using an Electrophilic Phosphorothioester. Nucleic Acids Res. 2017, 45 (12), 7042-7048. 